\title{
Insights from the Engineering Geological Mapping of Four Basement Rocks Derived Soils
}

\author{
Oluwaseun Franklin Olabode ${ }^{1, a^{*}}$ and Yinusa Ayodele Asiwaju-Bello ${ }^{2, b}$ \\ Applied Geology Department, The Federal University of Technology, Akure. P.M.B 704, Akure, \\ Nigeria \\ a*ofolabode@futa.edu.ng, seunwhyte@yahoo.co.uk, bayoasiwajubello@futa.edu.ng
}

Keywords: Basement rocks, Engineering geological mapping, strength, FUTA, soils

\begin{abstract}
Due to the rapid expansion and associated construction of civil engineering structures on the Federal University of Technology, Akure (FUTA) campus, there arose an urgent need for an engineering geological mapping of the underlying soils (residual soils). Generalized geological mapping revealed four types of basement rocks namely migmatite-gneisses, granites, quartzites and charnockites. Results from the fifty soil samples from twenty-five test pits collected all over the spread of the campus coverage of $6.4 \mathrm{~km}^{2}$ revealed that the campus is underlain by soils of granular and clayey composition, generally lateritic, having reddish to brownish colour. Engineering geological tests such as natural moisture content, particle size analysis, consistency limits, California bearing ratio and consolidation were carried out on the soils following standard procedures revealed that the values of natural moisture content do not generally follow a consistent pattern and varied from location to location. The grain size characteristics curve, displayed $84 \%$ and $16 \%$ subsoils are of well graded and poorly graded type respectively. The soils were grouped into CL (low plasticity), CI (medium plasticity) and $\mathrm{CH}$ (high plasticity) from consistency limits results. Compaction characteristics of the subsoils revealed $36 \%$ and $64 \%$ representative of fair to good and poor to very poor foundation materials respectively. Soils with settlement rates greater than $1 \mathrm{~mm} /$ year were designated as high settlement subsoils. $72 \%$ and $28 \%$ of the subsoils fell into hard to stiff and soft categories from the shear strength characteristics respectively, and classified as c- $\varnothing$ soils. California Bearing Ratios values range from 10-70, indicating their suitability for pavement construction. Conclusively, areas underlain by migmatite-gneiss and charnockite-derived soils, and granite and quartzite-derived soils possessed low and high strength characteristics respectively which can be attributed to their textural characteristics. The subsoils of the entire campus spread are however capable of bearing very substantial loads.
\end{abstract}

\section{Introduction}

Engineering geological mapping has been adjudged as a veritable approach employed in the development and planning of several civil and mining operations and its usages had risen in contemporary time [1]. This approach also helped in the planning of several countries such as United States, Slovakia, Tyne and Wear County England, United Kingdom, Nigeria (Niger Delta Basin, Abuja (Federal Capital City) and Benin City) and Northern Mekelle town, Tigray, Northern and Southern parts of Ethiopia [2]-[13]. However, all engineering geological mapping always result to the production of an engineering geological map with variations in scale. This map always contains the information about the engineering geological features of the area investigated/mapped in respect to the purpose of investigation. The obtained information often played advisory, preventory and planning roles for safe civil engineering works [7]. However, the information on the resulting engineering geological map must include engineering properties (be it physical, mechanical, index and strength) of engineering soils (residual and transported soils) and rocks, water conditions, geomorphological and geodynamical processes [7]. Typical engineering geological maps usually show all these features which were then subjected to classification and assessment by employing different relative weights such as severity, performance or recurrence, and difficult of amelioration [3]. It has been emphasized, that engineering geological maps cannot be 
used for selection of specific engineering sites, but are useful for preliminary planning of several civil and mining works [3]. Engineering geological map produced for Slovakia Tyne and Wear County, England was entirely a geological map with additional information on the hydrogeological situation, contemporary geodynamic processes, and thus four main engineering geological regions of the areas were classified [4]. This approach however was employed on a university campus spread (FUTA) which has not been reported in any literature but several authors [13]-[20] have also worked on the foundation studies of specific civil engineering structures in different higher institutions of learning.

Several problems such as differential settlement usually resulting from unfavorable engineering geological conditions have confirmed that engineering geological mapping is a fundamental prerequisite for planning [21]. Many engineering activities, foundations for buildings, roads, bridges, etc., are in most cases limited within the top few metres of the surface of the earth. Therefore, surficial material deposits such as engineering soils (residual soils) are of prime importance in most engineering geological and geotechnical investigations [7, 22].

The current research work took into consideration the present expansion (e.g. increasing population, lecture theatres, office blocks, school buildings and hostels) and futuristic growth of the Federal University of Technology, Akure campus based on its goal and objectives. This was achieved by generalized geological mapping and performing of index and strength tests on the abundant residual soils to appraise the soils in relation to planning and development of the campus. The results are meant to aid proper planning and development of the university campus by characterization of engineering properties of residual soils.

\section{Study area}

The study area covers about $6.4 \mathrm{~km}^{2}$, lies between Latitudes $7^{\circ} 17^{\prime} 0^{\prime \prime} \mathrm{N}-7^{\circ} 19^{\prime} 0^{\prime \prime} \mathrm{N}$ and Longitudes $5^{\circ} 7^{\prime} 0^{\prime}$ ' $\mathrm{E}-5^{\circ} 9^{\prime} 0^{\prime}$ ' $\mathrm{E}$, falls under humid tropical climate of the West African Monsoonal type with distinct wet and dry seasons [23].

Annual rainfall reaches mean value of about $1350 \mathrm{~mm}$ coupled with high temperatures reaching a peak of about $32^{\circ} \mathrm{C}$ around February and a threshold of about $21^{\circ} \mathrm{C}$ around August. Relative humidity ranges from about $70 \%$ to $90 \%$ (January to July) [23].

Vegetation in the study area is however of regrowth rainforest type with evident spread of grasses and scattered trees but had in many parts been modified with human activities such as civil engineering structures such as buildings, roads and land cultivation needed for the growth of the varsity.

The study area is a fast-growing Federal University of Technology which at present had only built up $45 \%$ of her land area [23]. Due to the rapid development on the campus following FUTA Campus Master Plan 2013-2022, there has been increasing number of on-going building projects.

\section{Topography, geological setting and drainage conditions of the study area}

The topography is undulating with the presence of depressions at the Southern part and fairly level plain at the Northern part of the study area. There are some ridges with their trends in the generally north-south direction. In some places, all the basement rocks except the charnockites occur as inselbergs which stand out against relatively low-lying surroundings (Fig. 1) [23]. The study area is well-drained and the streams draining the area flow southward. The stream directions are largely controlled by the trend of the rocks (Fig. 1). Most of the stream channels shows a meandering pattern while some flow in a straight pattern of about $300 \mathrm{~m}$ which can be suggested as fracture-controlled drainage system. The drainage is of medium density which is as a result of influence of climate, infiltration capacity and the vegetation cover. 


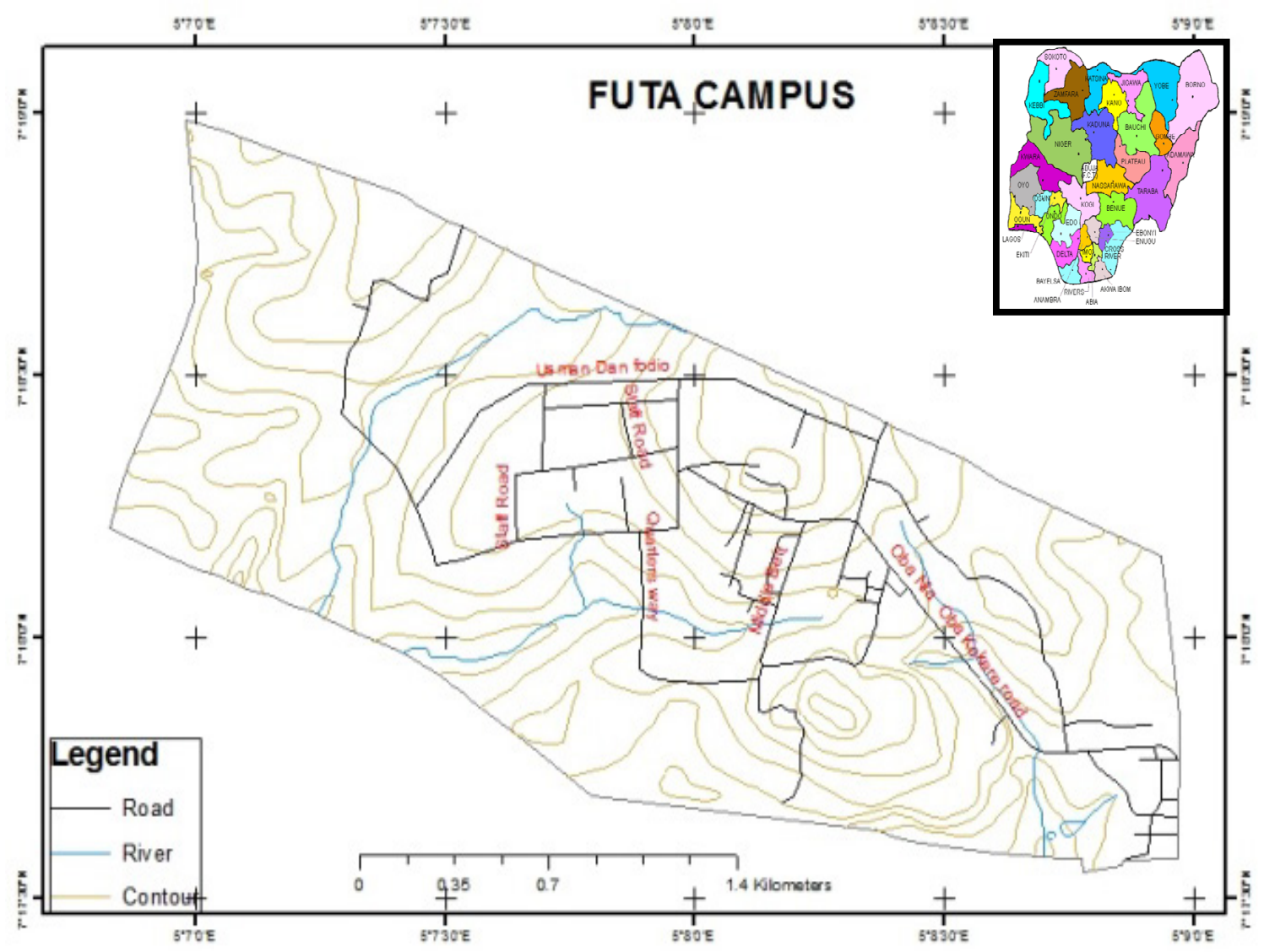

Figure 1. Topographical Map of the Federal University of Technology, Akure (FUTA) (Inset at top is map of Nigeria) [23].

\section{Materials and Methods}

Reconnaissance survey, field work, and generalized geological mapping of the study area were carried out. A total of twenty-five dug pits from which a total of fifty (50) soil samples comprises of twenty-five (25) disturbed and twenty-five (25) undisturbed soil samples were collected at depth of about $1 \mathrm{~m}$ in each of the pits.

The laboratory tests include determination of moisture content, grain size distribution, Atterberg limits (liquid and plastic limits), California bearing ratios, triaxial shear strength, consolidation and compaction were all undertaken at the Engineering Laboratory section an arm of the Department of Applied Geology, the Federal University of Technology, Akure (FUTA) Nigeria. The soil samples were tested according to the standard procedures [24]. Microsoft EXCEL, SURFER and GRAPHER softwares were used for statistical analysis and engineering geological map production respectively. The soils were classified according to American Association of State Highways and Officials (AASHTO) and United Soil Classification System (USCS).

The Terzaghi's ultimate soil-bearing capacity equation was applied in the determination of ultimate bearing capacity, allowable bearing pressure and allowable column load for square footing is as follows

$$
\begin{aligned}
& \mathrm{q}_{\mathrm{ult}}=1.3 \mathrm{cN}_{\mathrm{c}}+\mathrm{qN}_{\mathrm{q}}+0.4 \gamma \mathrm{BN} \gamma \\
& \mathrm{q}_{\mathrm{all}}=\mathrm{q}_{\mathrm{ult}} / \mathrm{F}_{\mathrm{s}}
\end{aligned}
$$

equation 1

equation 2

where $\mathrm{B}=$ diameter of the footing, $\mathrm{N}_{\mathrm{c}}, \mathrm{N}_{\mathrm{q}}$ and $\mathrm{N} \gamma$ are Terzaghi's Bearing Capacity Factors, $\mathrm{qult}_{\mathrm{u}}=$ ultimate bearing capacity, $\mathrm{q}_{\text {all }}=$ allowable bearing pressure and $\mathrm{F}_{\mathrm{s}}=$ factor of safety. The Terzaghi's Bearing Capacity Factors were obtained from the obtained angle of internal friction and cohesion 
reading in Terzaghi's Table. Also, $\mathrm{c}$ and $\mathrm{q}$ are cohesion and angle of internal friction values respectively. Factor of safety used was 2.5 , depth of groundwater was average of $4 \mathrm{~m}$. With square footing dimensions, width, length and depth to foundation of $2 \mathrm{~m}$ by $2 \mathrm{~m}$ by $2 \mathrm{~m}$ dimensions respectively.

\section{Results and Interpretation}

Summary of results of different engineering geological tests are presented in Tables 1-5 and Figs. 2-9.

\subsection{Generalized Geological Mapping of FUTA}

The rock types in the study area and from which the residual soils were developed are migmatite-gneisses, granites, charnockites, and quartzites of which they all conforms to the rocks that are associated with the Basement Complex of Nigeria (Fig. 2). The rocks were however not classified towards any civil engineering purposes.

\subsubsection{Granites}

The coarse grained granites cover about one-third of the study area to the south (Fig. 2). They are the dominant acid intrusives in the study area intruding migmatite-gneisses. These rocks have also undergone some degree of weathering.

\subsubsection{Migmatite gneisses}

The migmatite-gneisses cover the major part of the study area (Fig. 2) with deep contacts with the granites in the area. Their trends are usually north-south with feldspars aligned in the same direction with the other minerals. The migmatite-gneisses varied from medium to coarse grained, light grey to pinkish rock. Observed textures in these rocks are marked by mineralogical banding of the felsic and mafic minerals. They have foliation trending $138^{\circ}$ and $152^{\circ}$, also the rock is characterized with normal faults in some locations. Structures observed on the rock were shearing and folding.

\subsubsection{Quartzites}

These rocks only occur as a ridge, which covers smaller part of the study area (Fig. 2). They are massive in nature, coarse grained and with rubbles of quartz.

\subsubsection{Charnockites}

These are coarse-grained rocks of approximately granitic composition and granoblastic texture. They occur as discrete bodies, boulders and low lying outcrop and found along road cut and they occupied $10 \%$ of the study area (Fig. 2). 


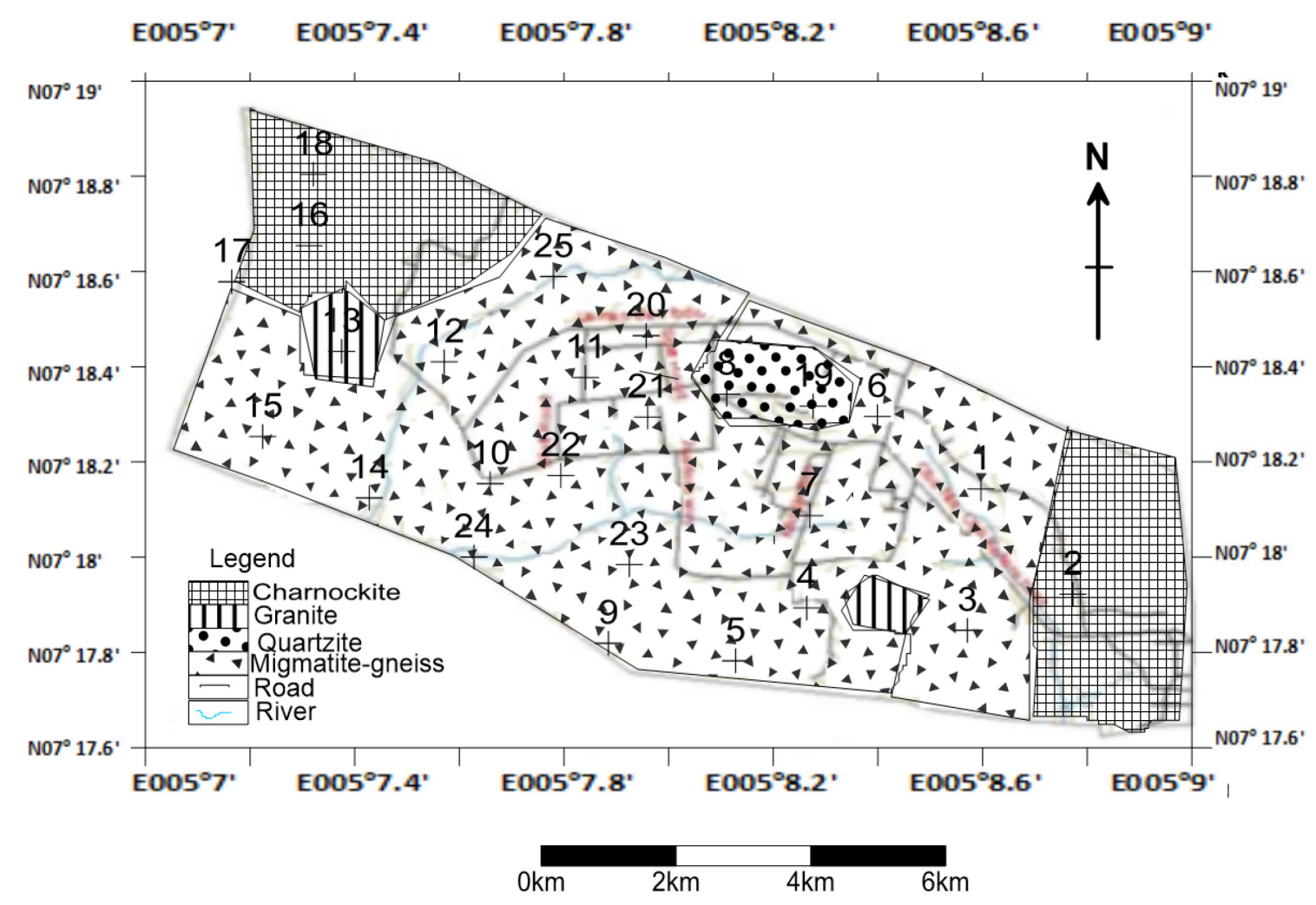

Figure 2. Generalized Geological map of the study area.

\subsection{Description of the Soils}

The sub-surface soils in the study area are composed largely of residual soils which are weathering products of the basement rocks. The soils are reddish to brownish in color due to presence of iron oxide, having medium to coarse-grained mineral matters with some clayey materials. They are characterized by mottled and sticky features in some locations. The soils of the study area resemble laterites in nature.

\subsubsection{Engineering Geological Index Characters of the FUTA soils}

The values of natural moisture content does not follow a general consistent pattern (Table 1) and they varied from location to location which may be due to nearness to the ground surface, prevailing rainfall condition and local drainage conditions [25]. High variation in the moisture contents may cause large volume changes in clayey soils and this can be used to trace the clay content and type in the soil [26]. The results when compared with proposition in [27] of natural moisture content values, twenty-three soils $(92 \%)$ fall within suitable to marginable engineering materials and two soils (8\%) fall within unsuitable engineering materials.

From the grain size characteristics curve plotted for all the soils in the study area, $84 \%$ of the subsoils are of well graded type which indicated they consisted of particles that will form a good framework for stress transfer (Fig. 3). They will be relatively stiff and strong, because the smaller particles fill fitly in the pores between the larger particles. They will definitely possess higher shear strengths, densities, reduced compressibilities, stabilities, bearing capacities and low permeabilities. This will also contribute to their suitability for creating road foundations and production of concretes. The remaining $16 \%$ subsoils are of poorly graded type which will possess lower shear strengths, densities, high compressibilities, low stabilities, lower bearing capacities and high permeabilities. This was also compared with the results obtained from the consolidation but two of the poorly graded soils confirmed this. The gradation textures also gives insight to the rate of leaching and weathering which can be related to the textural characteristics of the parent rock types. Well graded soils suggest decreasing degree of leaching and weathering and poorly graded soil suggest increasing degree of leaching and weathering. 
Table 1. Summary of engineering geological tests results on FUTA soils.

\begin{tabular}{|c|c|c|c|c|c|c|c|c|c|c|}
\hline Samples & $\begin{array}{c}\text { NMC } \\
(\%)\end{array}$ & $\begin{array}{l}\text { Sand } \\
(\%)\end{array}$ & $\begin{array}{c}\text { Gravel } \\
(\%)\end{array}$ & $\begin{array}{c}\text { Coarse } \\
(\%)\end{array}$ & $\begin{array}{c}\text { Fine }(\%) \\
\text { passing } 75 \\
\mu \mathrm{m}\end{array}$ & $\begin{array}{l}\mathrm{LL} \\
(\%)\end{array}$ & $\begin{array}{l}\text { PL } \\
(\%)\end{array}$ & $\begin{array}{c}\text { PI } \\
(\%)\end{array}$ & $\begin{array}{c}\mathrm{MDD} \\
\left(\mathrm{kg} / \mathrm{m}^{3}\right)\end{array}$ & $\begin{array}{c}\text { OMC } \\
(\%)\end{array}$ \\
\hline 1 & 17 & 23.6 & 39.4 & 62 & 38 & 42 & 24.1 & 17.9 & 1753 & 15.21 \\
\hline 2 & 19.5 & 29.2 & 20.4 & 49.6 & 50.4 & 49.5 & 33.3 & 16.2 & 1645 & 20 \\
\hline 3 & 16 & 34.8 & 20.8 & 55.6 & 44.4 & 40.8 & 20.2 & 20.6 & 1766 & 13.95 \\
\hline 4 & 8 & 39.2 & 36.5 & 75.7 & 24.3 & 33.2 & 18.5 & 14.7 & 1977 & 7.71 \\
\hline 5 & 22.5 & 29.1 & 6.4 & 35.5 & 64.5 & 54.8 & 25.1 & 29.7 & 1629 & 19.99 \\
\hline 6 & 11 & 31.9 & 36.5 & 68.5 & 31.5 & 60.2 & 22.7 & 37.5 & 1805 & 14.3 \\
\hline 7 & 13.5 & 51.6 & 3 & 54.6 & 45.4 & 29.2 & 15.5 & 13.7 & 1914 & 10.45 \\
\hline 8 & 17.5 & 28.6 & 45.1 & 73.7 & 26.3 & 50.6 & 26.2 & 24.4 & 1871 & 13.83 \\
\hline 9 & 18.5 & 23.2 & 23.2 & 45.4 & 54.6 & 53.8 & 27.7 & 26.1 & 1652 & 20.15 \\
\hline 10 & 26 & 11.2 & 1.9 & 13.1 & 86.9 & 65.8 & 40.7 & 25.1 & 1403 & 26.58 \\
\hline 11 & 12 & 32.1 & 26.5 & 58.9 & 41.1 & 47.4 & 41.6 & 5.8 & 1767 & 14.34 \\
\hline 12 & 12.5 & 30.3 & 38.9 & 69.2 & 30.8 & 37.8 & 21.5 & 16.3 & 1782 & 15.7 \\
\hline 13 & 16 & 26.1 & 42.2 & 68.3 & 31.7 & 51.6 & 23.5 & 28.1 & 1759 & 15.69 \\
\hline 14 & 13 & 14.9 & 57.7 & 71.6 & 28.4 & 54.18 & 29.6 & $\begin{array}{c}24.5 \\
8\end{array}$ & 1760 & 17.6 \\
\hline 15 & 19.5 & 30.1 & 3.8 & 33.9 & 66.1 & 47.4 & 25.2 & 22.2 & 1637 & 19.63 \\
\hline 16 & 19 & 27.5 & 12.3 & 39.8 & 60.2 & 57.8 & 30.2 & 27.6 & 1619 & 21.32 \\
\hline 17 & 19 & 35.2 & 13.8 & 49 & 51 & 47.4 & 28.2 & 19.2 & 1662 & 18.19 \\
\hline 18 & 18 & 29.1 & 20.2 & 49.3 & 50.7 & 58.2 & 29.6 & 28.6 & 1661 & 19.51 \\
\hline 19 & 16 & 40.9 & 2.5 & 43.4 & 56.6 & 51.6 & 23.4 & 28.2 & 1688 & 18.22 \\
\hline 20 & 15 & 45.8 & 0.2 & 46 & 54 & 42 & 23.8 & 18.2 & 1662 & 18.65 \\
\hline 21 & 14 & 39.3 & 16.1 & 55.4 & 44.6 & 47.3 & 22.3 & 25 & 1601 & 19.13 \\
\hline 22 & 13 & 30.6 & 36.8 & 67.4 & 32.6 & 41.9 & 18.6 & 23.3 & 1884 & 15 \\
\hline 23 & 18 & 37.1 & 26.4 & 63.5 & 36.5 & 44.1 & 27.3 & 16.8 & 1647 & 20.16 \\
\hline 24 & 9.5 & 30 & 40.1 & 70.1 & 29.9 & 44.1 & 12.9 & 31.2 & 1951 & 10 \\
\hline 25 & 15.5 & 36.6 & 2.8 & 39.4 & 60.6 & 32.3 & 17.1 & 15.2 & 1742 & 15.8 \\
\hline
\end{tabular}

Where $\mathrm{NMC}=$ Natural Moisture Content, $\mathrm{LL}=$ Liquid limit (\%), $\mathrm{PL}=$ Plastic limit (\%), PI= Plasticity Index $(\%), \mathrm{MDD}=$ Maximum Dry Density $\left(\mathrm{kg} / \mathrm{m}^{3}\right), \mathrm{OMC}=$ Optimum Moisture Content $(\%)$. 
GRAIN SIZE ANALYSIS

Client:

Project:

Location:

Borehole No.

Sieve Analysis

\begin{tabular}{|c|c|c|c|c|c|}
\hline \multicolumn{2}{|c|}{$\begin{array}{c}\text { Particle } \\
\text { Description }\end{array}$} & $\begin{array}{l}\text { Particle } \\
\text { Diameter } \\
\text { (mm) }\end{array}$ & $\begin{array}{c}\text { Mass } \\
\text { Retained } \\
(\mathrm{g})\end{array}$ & $\begin{array}{c}\text { Retained } \\
(\%)\end{array}$ & $\begin{array}{c}\text { Percent } \\
\text { Passing } \\
\text { (\%) }\end{array}$ \\
\hline & \multirow{2}{*}{ Cobbles } & 100.000 & & & 100.0 \\
\hline & & 75.000 & & & 100.0 \\
\hline \multirow[b]{7}{*}{ L } & \multirow{5}{*}{ Coarse } & 63.000 & & & 100.0 \\
\hline & & 37.500 & & & 100.0 \\
\hline & & 19.000 & & & 100.0 \\
\hline & & 14.000 & & & 100.0 \\
\hline & & 9.500 & & & 100.0 \\
\hline & \multirow{2}{*}{ Fine } & 4.750 & 117.80 & 24.27 & 75.7 \\
\hline & & 2.360 & 73.60 & 15.17 & 60.6 \\
\hline \multirow{7}{*}{$\begin{array}{l}S \\
A \\
N \\
D\end{array}$} & Coarse & 1.180 & 37.00 & 7.62 & 52.9 \\
\hline & \multirow{3}{*}{ Medium } & 0.850 & 13.80 & 2.84 & 50.1 \\
\hline & & 0.425 & 28.80 & 5.93 & 44.2 \\
\hline & & 0.300 & 12.40 & 2.56 & 41.6 \\
\hline & \multirow{3}{*}{ Fine } & 0.150 & 21.60 & 4.45 & 37.2 \\
\hline & & 0.075 & 0.80 & 0.16 & 37.0 \\
\hline & & 0.063 & 0.00 & 0.00 & 37.0 \\
\hline \multirow{3}{*}{ FINES } & \multirow{3}{*}{$\begin{array}{c}\text { Clay or } \\
\text { Silt }\end{array}$} & $<0.063$ & 179.50 & 36.99 & \\
\hline & & Sum & 305.80 & & \\
\hline & & Initial wgt & 485.30 & & \\
\hline
\end{tabular}

Date:

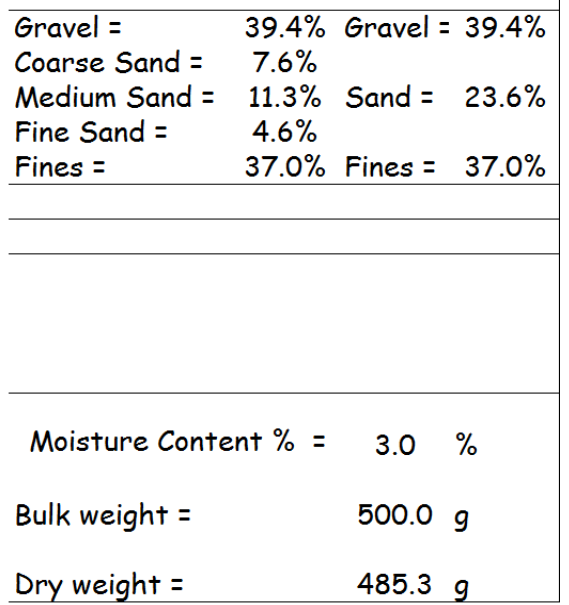

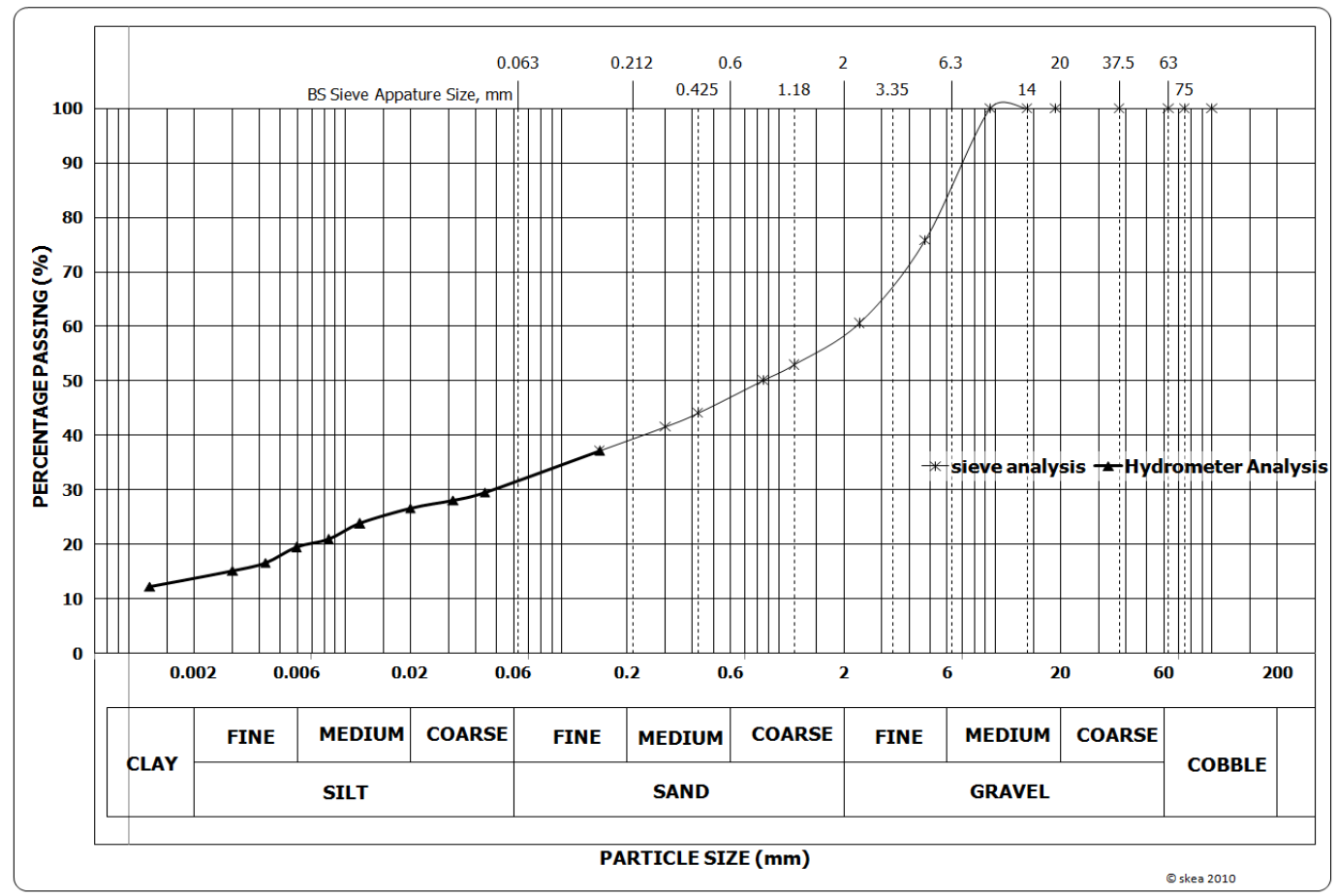

Figure 3. A typical grain size characteristic curve (Sample 1).

Low amount of fines (less than 35\%) and high amount of coarse contents (greater than 65\%) suggest low amount of micas and feldspars which was also observed on the granite outcrop and quartzite ridge. Soils with high amount of fines (greater than 35\%) and low amount of coarse contents (less than 65\%) suggest high amount of micas and feldspars which were also observed on 
the migmatite-gneisses and charnockites of the study area as shown in the spatial distribution map of the textural contents of the soils in the study area (Fig. 4).

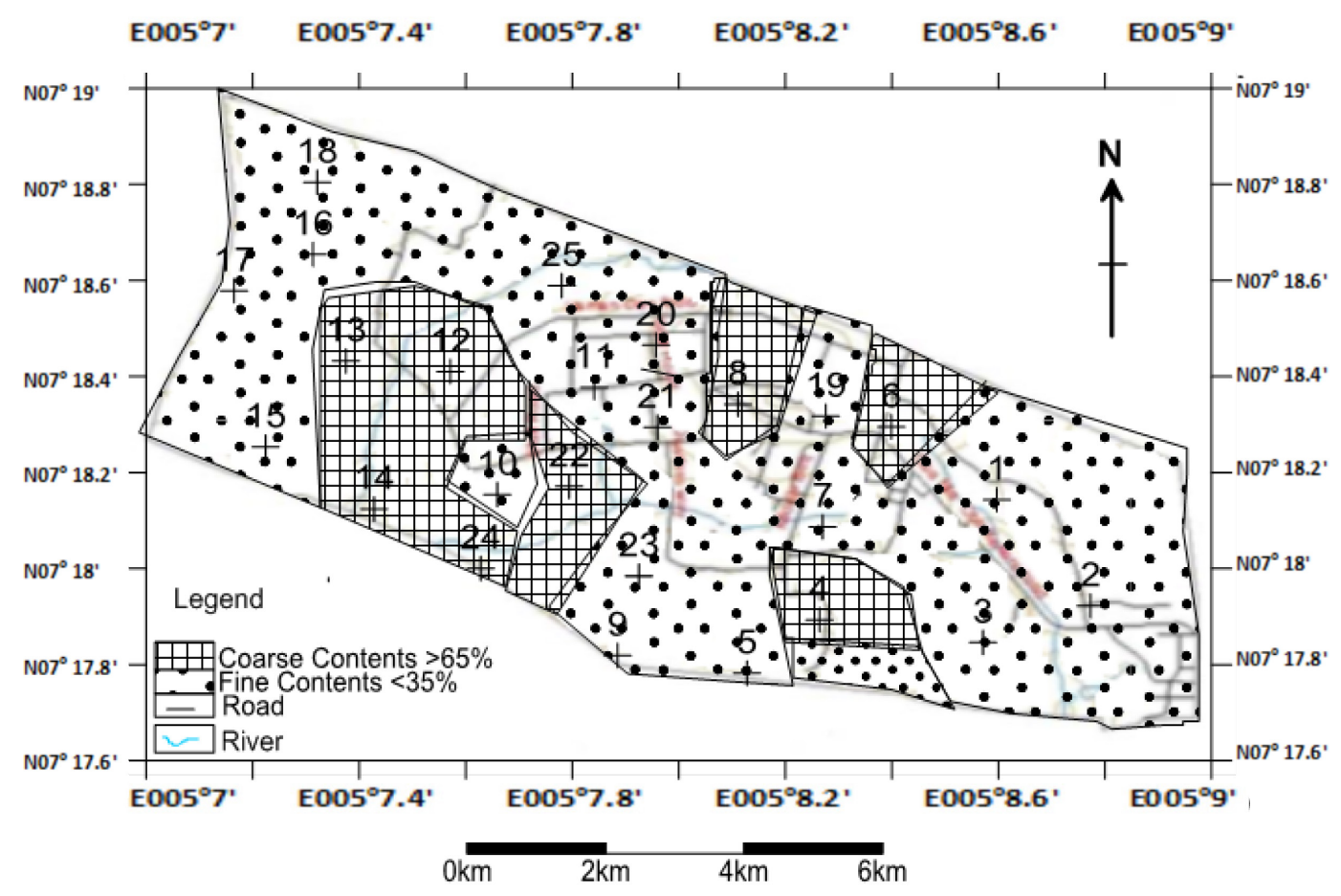

Figure 4. Engineering geological map based on their gradation textural characteristics.

Consistency limits tests such as liquid limits, plastic limits and plasticity indices were employed for classification purposes and predictions of its usages for civil engineering purposes. Applying [28] recommendations of 35\%,50\%,30\% and 20\% maximum limits for the percentage fines, liquid limit, plastic limit and plasticity index respectively for foundation materials. Fifteen samples fall within acceptable liquid limit values and low potential swell and ten samples fall above acceptable liquid limit values and marginal potential swell. This also indicates sixty percentages $(60 \%)$ and forty $(40 \%)$ of the residual soil samples have low potential and marginal potential swells potentials.

Twenty-one soils, (84\%) of the samples fall within acceptable plastic limit values and four soils (16\%) fall above the acceptable plastic limit values. Therefore, soils with organic content have low plasticity indices corresponding to comparatively high liquid limits [29]. Fifteen samples fall within low potential swell and ten samples fall within marginal potential swell, based on [30] plastic index classification. Those samples with low plasticity index (PI) might have their expansive clays converted to less expansive types [31]. Soils of low plasticity, have larger particles, possess a fewer number of inter-particle contact points and those soils of high plasticity are composed of very small particles, having relatively high surface area per unit weight, possess a large number of particles contact points. High plastic soils (four subsoils) will also be susceptible to high compressibility, swelling on moisture influx, low bearing capacity and leading to low permeability (low drainage) and hydraulic conductivity also possessing high swell potential $[26,32,33]$. The studied soils were then plotted on the Cassagrande plasticity chart, with three, twelve and eleven soil samples falling within low, medium and high plasticity zones, respectively. Plasticity was then correlated with compressibility, based on this fact, soil samples with low, medium and high plasticities will have low, medium and high compressibility respectively. Soils with very high liquid limit tend to possess low bearing capacity while low liquid limit soils tend to possess high bearing capacities.

The studied soil samples were classified into low plasticity (CL), medium plasticity (CI) and high plasticity $(\mathrm{CH})$ soils based on the following three soil characteristics; particle size distribution, liquid limit and plasticity index (Table 2; Fig. 5). Cassagrande's plasticity chart containing the Aline plays a major role in the classification. Three samples fall within low plasticity (CL), twelve 
fall within medium plasticity $(\mathrm{CI})$ while ten fall within high plasticity $(\mathrm{CH})$ categories. According to [15], these properties of high plasticity would probably negate few favorable properties, like high MDD and relatively high shear strength parameters and ultimately render it unsuitable for use for most construction purposes especially where moisture influx cannot be effectively controlled.

Table 2. Soil Classifications of FUTA Soils.

Table 2. Soil Classifications of FUTA Soils.

\begin{tabular}{|c|c|c|c|c|c|c|c|c|c|}
\hline Location & $\begin{array}{c}\text { Liquid } \\
\text { limit, } \\
\text { LL(\%) }\end{array}$ & $\begin{array}{c}\text { Plastic } \\
\text { limit, } \\
\text { PL(\%) }\end{array}$ & $\begin{array}{c}\text { Plasticity } \\
\text { index, PI } \\
(\%)\end{array}$ & $\begin{array}{c}\text { \%of } \\
\text { Soil } \\
\text { Passing } \\
2.36 \mathrm{~mm} \\
\text { sieve }\end{array}$ & $\begin{array}{c}\text { \% of } \\
\text { Soil } \\
\text { Passing } \\
425 \mu \mathrm{m} \\
\text { sieve }\end{array}$ & $\begin{array}{c}\text { \%of } \\
\text { Soil } \\
\text { Passing } \\
75 \mu \mathrm{m} \\
\text { sieve }\end{array}$ & $\begin{array}{c}\text { Group } \\
\text { index, } \\
\text { GI }\end{array}$ & $\begin{array}{c}\text { AASHTO } \\
\text { classifica- } \\
\text { tion }\end{array}$ & $\begin{array}{c}\text { USCS } \\
\text { Classifica- } \\
\text { tion code }\end{array}$ \\
\hline 1 & 42.0 & 24.1 & 17.9 & 60.6 & 44.2 & 37.0 & 2.2 & A-2-7 & CI \\
\hline 2 & 49.5 & 33.3 & 16.2 & 79.6 & 57.5 & 50.4 & 6.0 & A-7-5 & CI \\
\hline 3 & 40.8 & 20.2 & 20.6 & 79.2 & 57.7 & 44.4 & 5.0 & A-7-5 & CI \\
\hline 4 & 33.2 & 18.5 & 14.7 & 63.5 & 36.1 & 24.3 & 0.0 & A-2-6 & CL \\
\hline 5 & 54.8 & 25.1 & 29.7 & 93.6 & 75.5 & 64.5 & 17.8 & A-7-6 & CH \\
\hline 6 & 60.2 & 22.7 & 37.5 & 63.5 & 38.0 & 31.6 & 3.5 & A-2-7 & CH \\
\hline 7 & 29.2 & 15.5 & 13.7 & 97.0 & 68.4 & 45.5 & 2.7 & A-2-6 & CL \\
\hline 8 & 50.6 & 26.2 & 24.4 & 54.9 & 31.0 & 26.3 & 0.0 & A-2-7 & CH \\
\hline 9 & 53.8 & 27.7 & 26.1 & 76.8 & 60.8 & 53.6 & 11.2 & A-7-6 & CH \\
\hline 10 & 65.8 & 40.7 & 25.1 & 98.1 & 91.0 & 86.9 & 20.0 & A-7-5 & CH \\
\hline 11 & 47.4 & 41.6 & 5.8 & 73.5 & 51.5 & 41.4 & 0.4 & A-7-6 & CI \\
\hline 12 & 37.8 & 21.5 & 16.3 & 61.1 & 39.9 & 30.8 & 0.2 & A-2-6 & CI \\
\hline 13 & 51.6 & 23.5 & 28.1 & 57.8 & 37.7 & 31.7 & 2.2 & A-2-7 & CH \\
\hline 14 & 54.2 & 29.6 & 24.6 & 42.3 & 30.4 & 27.4 & 0.0 & A-2-7 & CH \\
\hline 15 & 47.4 & 25.2 & 22.2 & 96.2 & 78.6 & 66.1 & 13.6 & A-7-6 & CI \\
\hline 16 & 57.8 & 30.2 & 27.6 & 87.7 & 67.9 & 60.2 & 15.2 & A-7-5 & CH \\
\hline 17 & 47.4 & 28.2 & 19.2 & 86.2 & 61.9 & 50.9 & 7.1 & A-7-6 & CI \\
\hline 18 & 58.2 & 29.6 & 28.6 & 79.8 & 57.7 & 50.7 & 11.2 & A-7-6 & CH \\
\hline 19 & 51.6 & 23.4 & 28.2 & 97.5 & 74.4 & 56.6 & 13.1 & A-7-6 & CH \\
\hline 20 & 42.0 & 23.8 & 18.2 & 99.8 & 75.8 & 54.0 & 7.2 & A-7-6 & CI \\
\hline 21 & 47.3 & 22.3 & 25.0 & 83.9 & 57.6 & 44.6 & 6.7 & A-7-6 & CI \\
\hline 23 & 41.9 & 18.6 & 23.3 & 63.2 & 44.1 & 32.6 & 1.8 & A-2-7 & CI \\
\hline 25 & 44.1 & 27.3 & 16.8 & 73.6 & 48.0 & 36.6 & 1.8 & A-2-7 & CI \\
\hline & 44.1 & 12.9 & 31.2 & 59.9 & 42.2 & 29.8 & 2.0 & A-2-7 & CI \\
\hline & 17.3 & 15.2 & 97.2 & 78.2 & 60.6 & 6.5 & A-7-6 & CI \\
\hline
\end{tabular}

Where AASHTO $=$ American Association of State Highways and Officials, USCS $=$ United Soil and Classification System. 


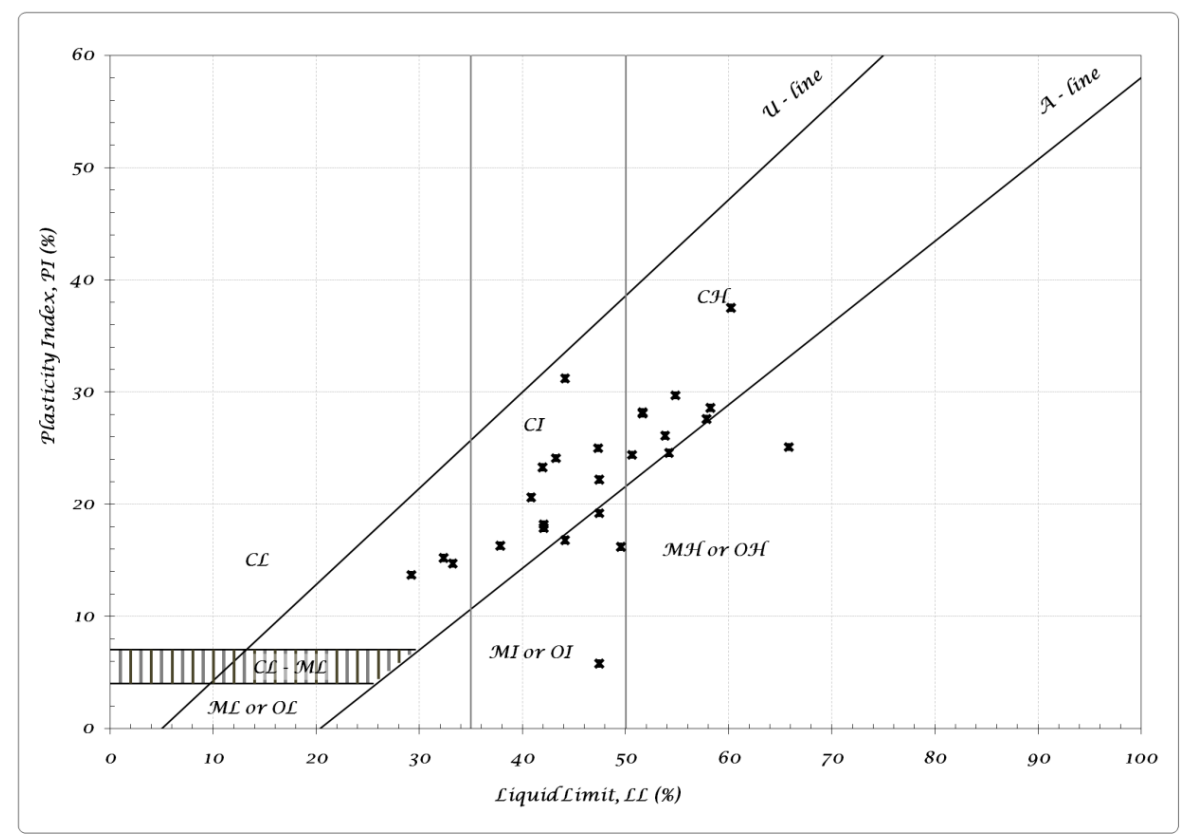

Figure 5. Plot of tested samples on the USCS classification chart.

The result of AASHTO classification shows that ten of the tested soils classify as A-7-6 soils, nine classify as A-2-7 soils, while three classify as A-7-5 soils, and the remaining three classify as A-2-6 soils. This classification denotes two type of soils namely granular soils (A-2-6 and A-2-7) and clayey soils (A-7-5 and A-7-6). The granular soils are considered suitable for road construction materials while the clayey soils are considered unsuitable for road construction materials. It follows that the suitability of the soils as road construction materials is low, and this worsens southward. They can only be successfully used for base and sub-base courses after stabilization.

\subsubsection{Engineering Geological Strength Characters of the FUTA soils}

Theoretically and practically from compaction test, the best soils are those that have high maximum dry density values at relatively low optimum moisture content [34]. Based on [35] proposition, two out of the tested soils fall within the good foundation materials category, seven soils fall within the fair foundation materials category, fourteen soils fall within poor foundation materials category and two soils fall within the very poor foundation materials category (Table 1; Figs. 6 and 7). Low maximum dry density value of subsoils is a prediction to the future occurrence of construction failures in the study area. 


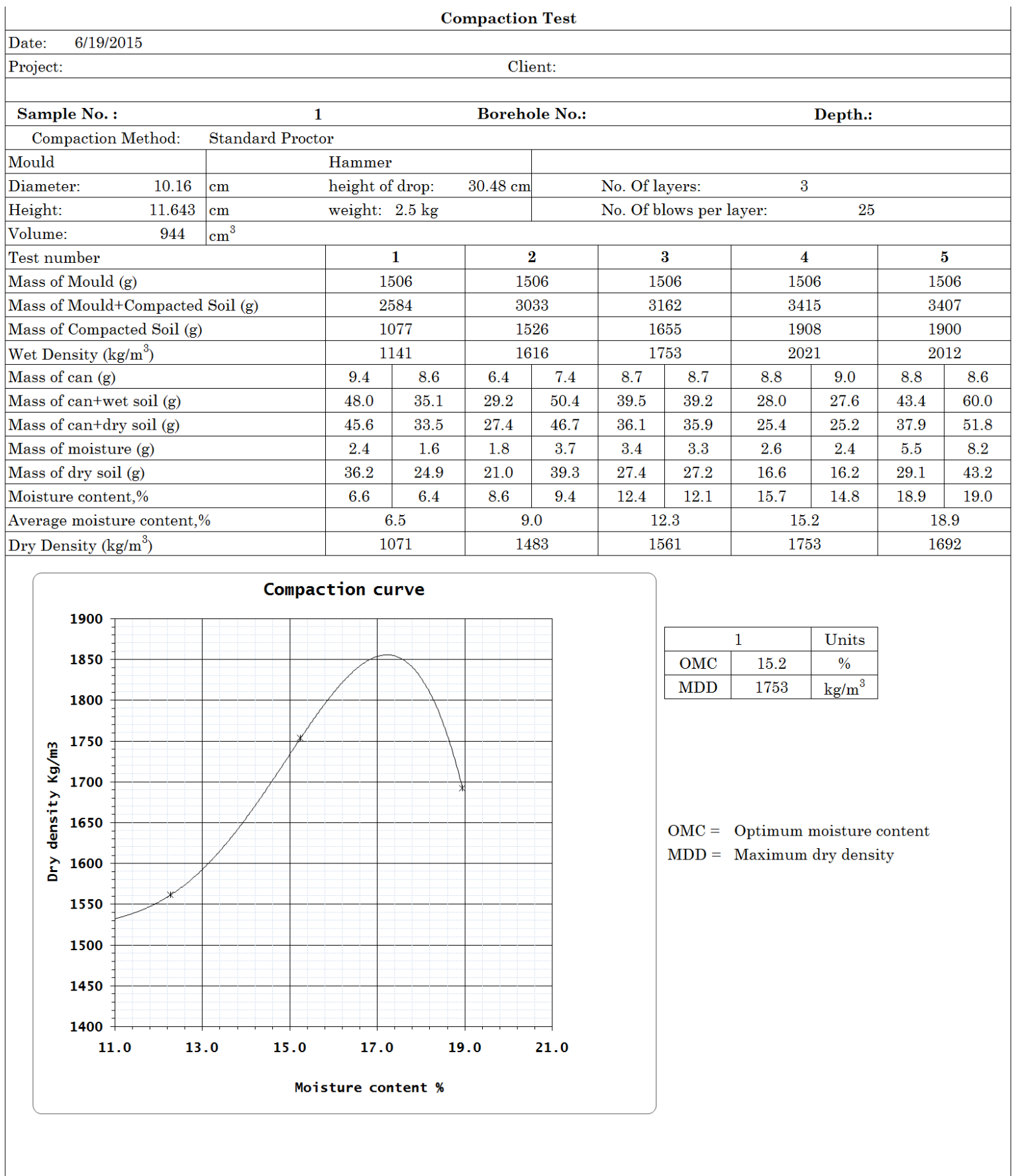

Figure 6. A typical compaction curve (Sample 1). 


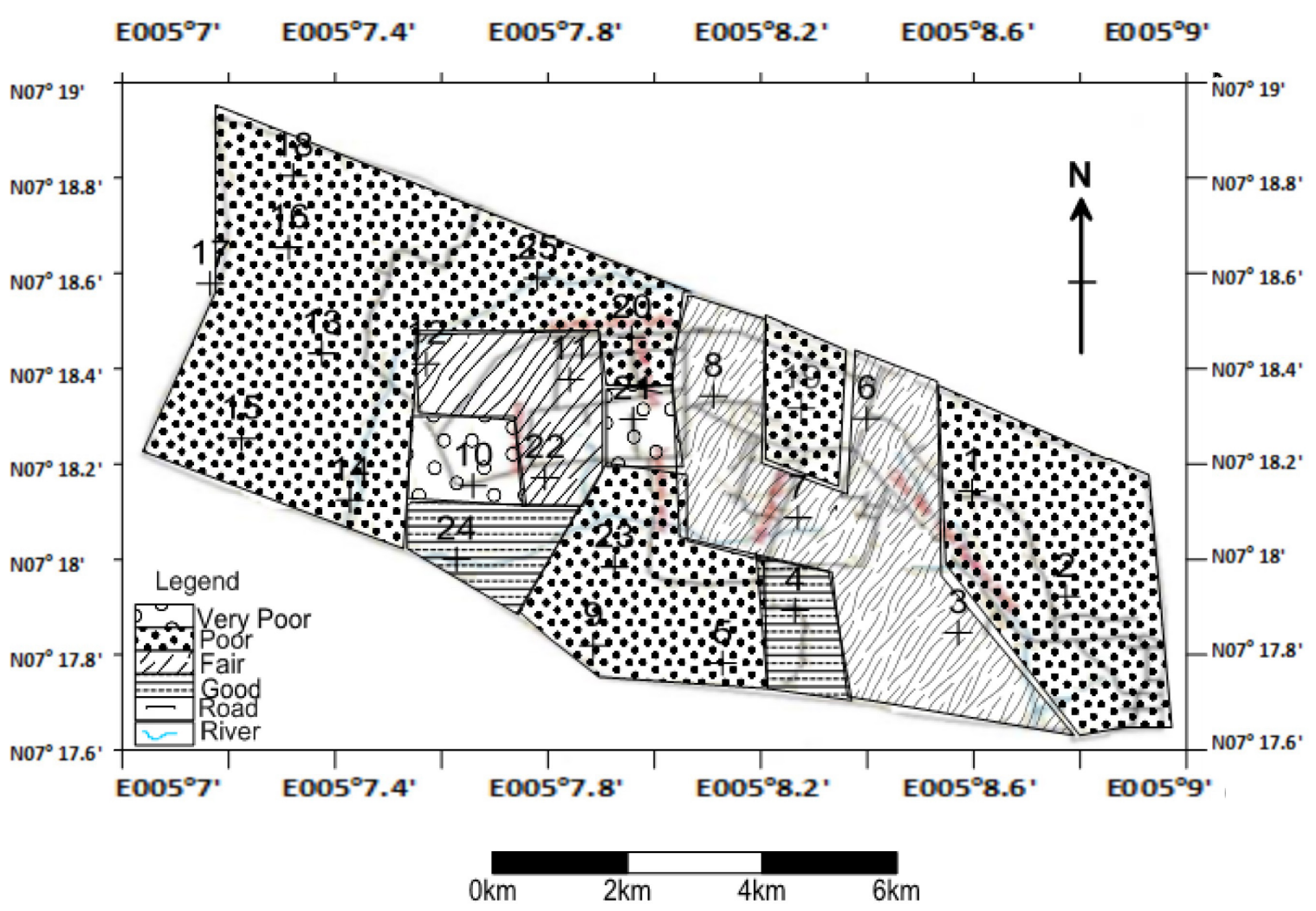

Figure 7. Engineering geological map based on their compaction characteristics.

It was also observed that all the soils with coarse contents greater than $65 \%$ are characterized with averagely higher MDD values which fall within fair to good engineering materials according to [35] classification. Evidence of this was traced to the low degree of weathering of the parent rocks. Those soils with fine contents greater than 35\% were characterized with lower MDD values which fall within poor to very poor engineering materials according to [35] classification. They are believed to have resulted from the higher degree of weathering of the parent rocks.

The one-dimensional consolidation test was adopted for this study in the determination and calculation of the magnitude and rate of settlement of the soils in the study area. The loadsettlement data obtained from the full cycle of loading and unloading are used to draw a pressurevoids ratio curve from which the coefficient of volume compression $\left(\mathrm{m}_{\mathrm{v}}\right)$ is derived. This was used to calculate the magnitude of consolidation settlement under any given loading.

The rate of settlement ranges from 0.596 to $1.614 \mathrm{~mm} / \mathrm{yr}$, the pre-consolidation pressure obtained using the Cassagrande method (void ratio-pressure plot) ranges from 0.0236 to 0.0589 and the coefficient of volume compressibility $\left(\mathrm{m}_{\mathrm{v}}\right)$ ranges from 0.190 to 0.458 (Table 3 ).

Soils with settlement rates greater than $1 \mathrm{~mm} /$ year portend high settlement and these high values are not related to shallow water table because the water table is at deep depth and can therefore not contribute to any settlement of the subsoil. The cause of the high settlement values are possibly related to the deep weathering of locally enriched zones of feldspars in the original parent rocks [20]. The settlement rates in most places in the study area are believed to be influenced by genetic similarities between them as this almost followed the route of compaction results with the underlying geology. It has been established that the values of coefficient of consolidation varies with the presence of pore spaces in the soils. Soils with lower coefficient of consolidation values are suggestive of soils of clayey type and low permeability while those with higher coefficient of consolidation values are suggestive of granular (sandy clayey) soils characteristics of high permeability.

Applying USCS classification, seven samples fall within soft category (where angle of internal friction is less than $20^{\circ}$ ), seventeen fall within the hard category (where angle of internal friction is between $20-35^{\circ}$ ) and only one sample falls within the stiff category (where angle of 
internal friction is greater than $35^{\circ}$ ). Soils that fall within the hard and stiff categories suggest that they will serve as subgrade materials for road construction. These soils would have considerable strength, could withstand shear stresses, and be of high bearing capacity during the engineering life of civil engineering projects on the university campus. These types of soils suggest the absence of minerals that can bring about drastic change in their properties. Those soils that fall within soft category cannot serve as subgrade materials. This will be of unsuitable construction materials with lesser strength, and are not likely to withstand shear stresses. They will also be of low bearing capacities during the engineering life of civil engineering projects on the university campus.

Table 3. Summary of the results from Consolidation, Shear strength and California Bearing Ratios Tests.

\begin{tabular}{|c|c|c|c|c|c|c|c|}
\hline Samples & $\sigma_{\mathrm{p}}$ & $\mathrm{m}_{\mathrm{v}}$ & $\begin{array}{c}\mathrm{S} \\
(\mathrm{mm} / \mathrm{yr})\end{array}$ & $\begin{array}{c}\text { Internal } \\
\text { Friction } \\
\text { Angle }\end{array}$ & $\begin{array}{c}\text { Cohesion } \\
(\mathrm{o})\end{array}$ & $\begin{array}{c}\text { Shear } \\
\text { Strength } \\
(\mathrm{Kpa})\end{array}$ & $\begin{array}{c}\mathrm{CBR} \\
(\%)\end{array}$ \\
\hline 1 & 0.024 & 0.458 & 0.6 & 22.1 & 10.1 & 38.4915 & $44 \%$ \\
\hline 2 & 0.043 & 0.443 & 1.05 & 32.9 & 10.6 & 123.468 & $10 \%$ \\
\hline 3 & 0.042 & 0.52 & 1.19 & 14.9 & 30.5 & 29.6212 & $22 \%$ \\
\hline 4 & 0.05 & 0.272 & 0.68 & 26.2 & 24.4 & 81.3164 & $70 \%$ \\
\hline 5 & 0.047 & 0.404 & 0.97 & 16.8 & 26.6 & 35.0394 & $18 \%$ \\
\hline 6 & 0.041 & 0.433 & 0.73 & 18.8 & 99.3 & 103.534 & $25 \%$ \\
\hline 7 & 0.051 & 0.409 & 1.11 & 18.2 & 19.2 & 36.1677 & $26 \%$ \\
\hline 8 & 0.058 & 0.19 & 0.59 & 16.7 & 79.7 & 73.4509 & $65 \%$ \\
\hline 9 & 0.053 & 0.356 & 1.21 & 29.9 & 77.9 & 199.552 & $14 \%$ \\
\hline 10 & 0.059 & 0.314 & 1.61 & 32.1 & 10 & 88.5895 & $21 \%$ \\
\hline 11 & 0.055 & 0.253 & 0.95 & 29.6 & 43.2 & 144.455 & $31 \%$ \\
\hline 12 & 0.051 & 0.357 & 0.96 & 25.9 & 35 & 94.9891 & $38 \%$ \\
\hline 13 & 0.045 & 0.443 & 1.03 & 31.9 & 46.4 & 162.022 & $52 \%$ \\
\hline 14 & 0.053 & 0.264 & 0.81 & 22.3 & 120.2 & 159.282 & $37 \%$ \\
\hline 15 & 0.05 & 0.407 & 1.31 & 12.5 & 22.2 & 19.672 & $20 \%$ \\
\hline 16 & 0.054 & 0.307 & 1.16 & 15.9 & 32.6 & 36.3279 & $29 \%$ \\
\hline 17 & 0.051 & 0.255 & 0.93 & 18.2 & 19.2 & 36.1677 & $24 \%$ \\
\hline 18 & 0.042 & 0.24 & 0.66 & 29.9 & 14.9 & 89.2678 & $43 \%$ \\
\hline 19 & 0.053 & 0.249 & 0.99 & 10.6 & 46.1 & 23.5944 & $30 \%$ \\
\hline 20 & 0.026 & 0.39 & 0.64 & 21.4 & 24 & 43.8666 & $14 \%$ \\
\hline 21 & 0.051 & 0.341 & 1.08 & 22.4 & 31.5 & 114.803 & $27 \%$ \\
\hline 22 & 0.047 & 0.132 & 0.45 & 36.4 & 5.7 & 169.502 & $22 \%$ \\
\hline 23 & 0.056 & 0.222 & 0.95 & 25 & 62.4 & 119.777 & $44 \%$ \\
\hline 24 & 0.058 & 0.174 & 0.96 & 31.5 & 66.7 & 202.495 & $25 \%$ \\
\hline 25 & 0.026 & 0.41 & 0.65 & 20.5 & 9.3 & 34.0901 & $22 \%$ \\
\hline
\end{tabular}

$\sigma_{\mathrm{p}}=$ pre-consolidation pressure, $\mathrm{m}_{\mathrm{v}}=$ coefficient of volume compressibility, $\mathrm{S}=$ Settlement $(\%)$

Spatial distribution maps were drawn for the soils based on the obtained properties and these was used to classify the soils into three, namely low, medium and high shear strengths characters (Fig. 8). The shear strength characters displayed similarities in the presence of the parent rocks with migmatite-gneiss and charnockites contributing to low to medium shear strengths characters while granites and quartzites contributing to high shear strength characters. 


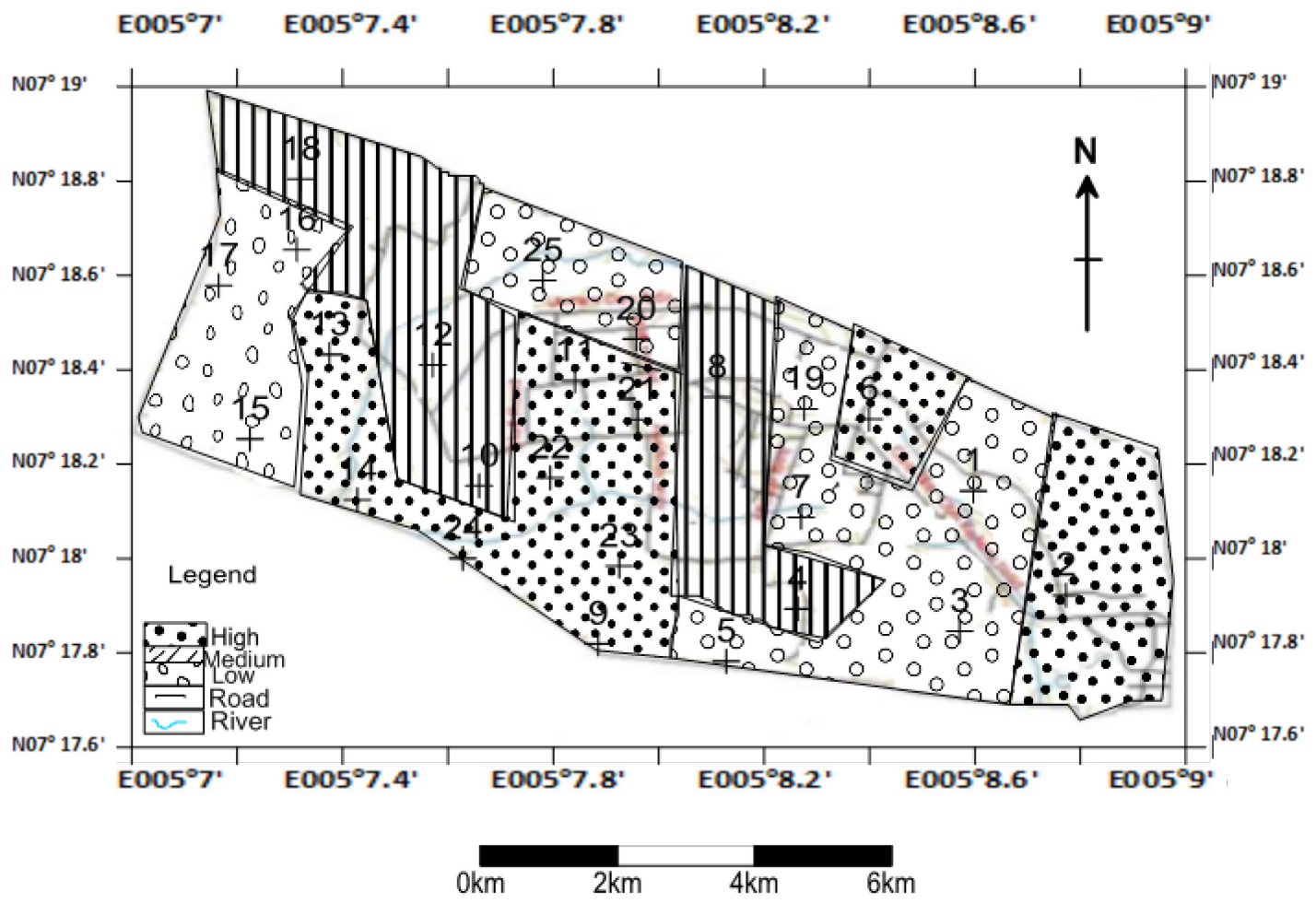

Figure 8. Engineering geological map based on their undrained shear strength characteristics.

California Bearing Ratios which has been adjudged as an indication of soils strength for the proper evaluation of highway, road and footpath subgrade and subbase materials [36]-[38]. CBR has also been correlated with pavement performance and applied in the establishment of design curves for pavement thickness [26, 39, 40]. [41], however recommends a California Bearing Ratio of greater than $10 \%$ for subgrade materials. The subsoils usages based on the California Bearing Ratio result, could be subdivided into three foundation purposes namely Base, Sub-grade and Subbase usages. Two soils in the study area have the capacity to serve as base materials, fifteen soils have the capacity to be employed as subgrade materials and the remaining eight soils have the capacity to be used as sub-base materials (Table 4).

Table 4. Summary of unsoaked California Bearing Ratio results.

\begin{tabular}{|c|c|c|c|}
\hline Location & unsoaked CBR & General Rating & Use \\
\hline 1 & $44 \%$ & Good & sub-base \\
\hline 2 & $10 \%$ & Good & subgrade \\
\hline 3 & $22 \%$ & Excellent & subgrade \\
\hline 4 & $70 \%$ & Good & base \\
\hline 5 & $18 \%$ & Good & subgrade \\
\hline 6 & $25 \%$ & Excellent & subgrade \\
\hline 7 & $26 \%$ & Excellent & subgrade \\
\hline 8 & $65 \%$ & Good & base \\
\hline 9 & $14 \%$ & Good & subgrade \\
\hline 10 & $21 \%$ & Excellent & subgrade \\
\hline 11 & $31 \%$ & Good & sub-base \\
\hline 12 & $38 \%$ & Good & sub-base \\
\hline 13 & $52 \%$ & Good & sub-base \\
\hline 14 & $37 \%$ & Good & sub-base \\
\hline
\end{tabular}




\begin{tabular}{|l|l|l|l|}
\hline 15 & $20 \%$ & Excellent & subgrade \\
\hline 16 & $29 \%$ & Excellent & subgrade \\
\hline 17 & $24 \%$ & Excellent & subgrade \\
\hline 18 & $43 \%$ & Good & sub-base \\
\hline 19 & $30 \%$ & Good & sub-base \\
\hline 20 & $14 \%$ & Good & subgrade \\
\hline 21 & $27 \%$ & Excellent & subgrade \\
\hline 22 & $22 \%$ & Excellent & subgrade \\
\hline 23 & $44 \%$ & Good & sub-base \\
\hline 24 & $25 \%$ & Excellent & subgrade \\
\hline 25 & $22 \%$ & Excellent & subgrade \\
\hline
\end{tabular}

All the studied soils, on the basis of their CBR values will not pose any failure of highway pavements, roads and footpaths (walkways) in the study area (Fig. 9). Seven subsoil samples located close to the drainage systems in the campus were discovered to still possess high coarse contents and low settlements rates except soil sample 7 with high settlements, it can be then deduced that drainage does not directly influence the settlement rates of soils but the underlying geology influenced the engineering properties of soils in the study area.

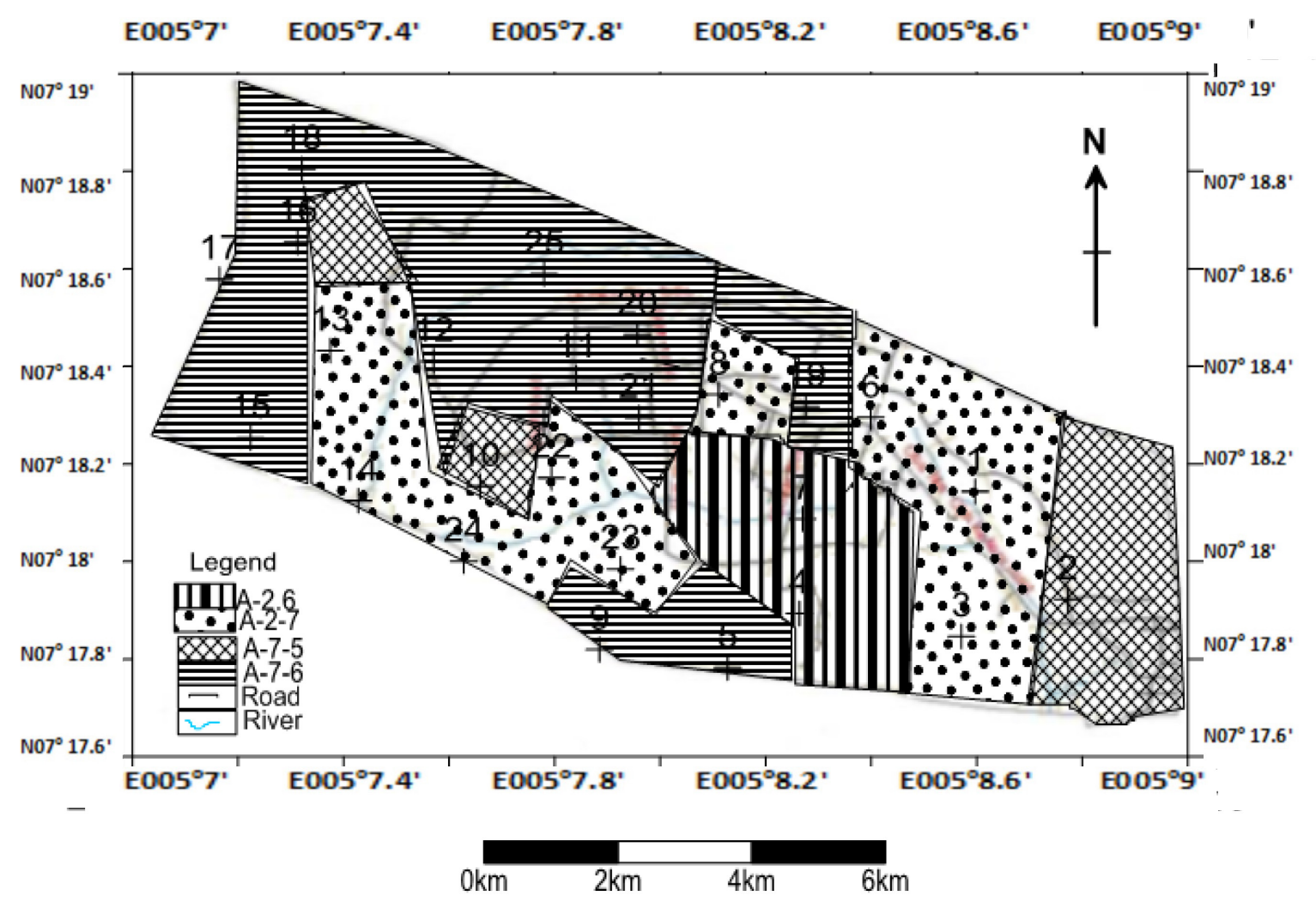

Figure 9. Engineering geological map based on their highway characters.

\subsubsection{Undisturbed Tests}

Moisture content values ranged from 7.09 to $17.85 \%$ and bulk density values varied from 16.41 to $23.94 \mathrm{KN} / \mathrm{m}^{3}$ (Table 5). From Terzaghi bearing capacity formula, the ultimate bearing capacity ranges from 464 to $5214 \mathrm{KPa}$, allowable bearing pressures ranges from 185 to $2085 \mathrm{KPa}$ and allowable column loads range from 553 to $8153 \mathrm{KN}$. The variation in the bearing capacities and allowable bearing pressures is traceable to the different kinds of soils in FUTA as observed from the AASHTO classification, depth of soil collection, loading form and type [42]. These also confirm that the soils ranged from fairly competent to competent in bearing very substantial loads. 
Table 5. Summary of results from undisturbed soil tests.

\begin{tabular}{|r|l|l|l|l|l|l|l|r|r|r|}
\hline Samples & A & B & C & D & E & F, & G & H & I & J \\
\hline 1 & 7.09 & 1.81 & 1.69 & 0.54 & 0.35 & 7.09 & 17.74 & 682 & 273 & 903 \\
\hline 2 & 15.49 & 1.81 & 1.57 & 0.66 & 0.40 & 15.49 & 17.79 & 2255 & 902 & 3419 \\
\hline 3 & 13.19 & 1.91 & 1.69 & 0.52 & 0.34 & 13.19 & 18.74 & 704 & 282 & 937 \\
\hline 4 & 7.60 & 1.87 & 1.74 & 0.52 & 0.34 & 7.60 & 18.34 & 1567 & 627 & 2318 \\
\hline 5 & 17.05 & 1.80 & 1.54 & 0.68 & 0.41 & 17.05 & 17.62 & 725 & 290 & 971 \\
\hline 6 & 11.17 & 1.90 & 1.71 & 0.52 & 0.34 & 11.17 & 18.63 & 2410 & 964 & 3667 \\
\hline 7 & 10.42 & 2.24 & 2.03 & 0.27 & 0.21 & 10.42 & 21.94 & 723 & 289 & 968 \\
\hline 8 & 7.83 & 2.29 & 2.12 & 0.24 & 0.19 & 7.83 & 22.43 & 1767 & 707 & 2638 \\
\hline 9 & 16.01 & 1.98 & 1.71 & 0.51 & 0.34 & 16.01 & 19.43 & 4902 & 1961 & 7655 \\
\hline 10 & 14.39 & 1.89 & 1.65 & 0.52 & 0.34 & 14.39 & 18.51 & 2068 & 827 & 3121 \\
\hline 11 & 11.71 & 1.71 & 1.53 & 0.68 & 0.40 & 11.71 & 16.73 & 2989 & 1195 & 4593 \\
\hline 12 & 10.63 & 1.85 & 1.68 & 0.59 & 0.37 & 10.63 & 18.19 & 1888 & 755 & 2813 \\
\hline 13 & 13.81 & 1.85 & 1.62 & 0.58 & 0.37 & 13.81 & 18.12 & 4054 & 1622 & 6298 \\
\hline 14 & 9.70 & 2.44 & 2.23 & 0.22 & 0.18 & 9.70 & 23.94 & 3807 & 1523 & 5902 \\
\hline 15 & 13.13 & 1.81 & 1.60 & 0.60 & 0.38 & 13.13 & 17.72 & 464 & 185 & 553 \\
\hline 16 & 15.12 & 1.93 & 1.67 & 0.57 & 0.36 & 15.12 & 18.89 & 797 & 319 & 1087 \\
\hline 17 & 17.85 & 1.90 & 1.61 & 0.62 & 0.38 & 17.85 & 18.65 & 673 & 269 & 888 \\
\hline 18 & 10.48 & 1.87 & 1.69 & 0.52 & 0.34 & 10.48 & 18.35 & 1819 & 728 & 2721 \\
\hline 19 & 17.54 & 1.85 & 1.58 & 0.70 & 0.41 & 17.54 & 18.16 & 716 & 286 & 956 \\
\hline 20 & 14.49 & 1.75 & 1.52 & 0.67 & 0.40 & 14.49 & 17.12 & 976 & 390 & 1373 \\
\hline 21 & 16.04 & 1.78 & 1.54 & 0.68 & 0.41 & 16.04 & 17.49 & 1276 & 511 & 1853 \\
\hline 22 & 10.43 & 2.00 & 1.81 & 0.43 & 0.30 & 10.43 & 19.60 & 3393 & 1357 & 5241 \\
\hline 23 & 14.06 & 1.67 & 1.47 & 0.83 & 0.45 & 14.06 & 16.41 & 2577 & 1031 & 3934 \\
\hline 24 & 8.91 & 2.14 & 1.96 & 0.35 & 0.26 & 8.91 & 20.95 & 5214 & 2085 & 8153 \\
\hline 25 & 11.78 & 2.03 & 1.82 & 0.42 & 0.30 & 11.78 & 19.93 & 609 & 244 & 786 \\
\hline & & & & & & & & & 3 & \\
\hline
\end{tabular}

Where $\mathrm{A}=$ moisture content $(\%), \mathrm{B}=$ bulk density $\left(\mathrm{KN} / \mathrm{m}^{3}\right), \mathrm{C}=$ dry density $\left(\mathrm{KN} / \mathrm{m}^{3}\right) \mathrm{D}=$ void ratio, $\mathrm{E}=$ porosity, $\mathrm{F}=$ water content $(\%), \mathrm{G}=$ bulk unit weight, $\mathrm{H}=$ ultimate bearing capacity $\left(\mathrm{q}_{\mathrm{u}}\right)(\mathrm{KPa})$, $\mathrm{I}=$ allowable bearing pressure $\left(\mathrm{q}_{\mathrm{all}}\right)(\mathrm{KPa})$ and $\mathrm{J}=$ allowable column load $(\mathrm{P})(\mathrm{KN})$.

\section{Conclusion}

Residual soils derived from granitic and quartzitic rocks possess the highest strength while those derived from migmatite-gneissic and charnockitic rocks possess lesser strength for foundation and construction purposes. Results of compaction, triaxial shear strength, and consolidation and California Bearing Ratio tests also confirmed that subsoils are generally made of cohesive-frictional particles and have appreciable amount of cohesive (clay) binders to resist substantial shear force. The plasticity of the soils also qualifies them to be suitable for clay bricks and certain ceramics since larger percentage of the soils fall above the A-line on the Cassagrande plasticity chart, indicating that they are essentially inorganic clays.

Spatial distribution maps of the soils drawn for particle size distribution, plasticity, compaction, California bearing ratio, and consolidation data then revealed the influences of genetic similarities on the properties of the residual soils. This gave a generalized grouping of the soils. The degree of weathering is also believed to influence the amount of coarse and fine contents. High degree of weathering is responsible for the high fine contents resulting from enrichment of feldspar which weather into clay. Low degree of weathering is perceived to have influenced the high amount of coarse contents which reflect the depletion in enrichment of feldspar and enrichment of resistant quartz minerals in granites and quartzite ridges. Residual soils derived from migmatite-gneissic and 
charnockitic rocks possess higher amount of fines which can be attributed to high degree of weathering. This also resulted in the low strengths observed from their low MDD values, internal frictional angles and high settlement rates. On the other hand, subsoils derived from granites and quartzites possess high amount of coarse particles which can be attributed to low degree of weathering. This also resulted in the high strengths observed from their high MDD values, shear strengths, internal frictional angles, CBR and low settlement rates. Seven of the eight samples taken close to the drainage systems in the study area were discovered to possess high coarse contents and low settlements rates. It can then be deduced that drainage alone does not directly influence the settlement rates of soils, rather the interaction between the underlying geology and the drainage. These also confirm that the soils ranged from fairly competent to competent in bearing very substantial loads at shallow depth.

\section{Recommendation}

The few soils that show high plasticity (expansive) in the study area can be stabilized mechanically and chemically to increase its strength and enhance its uses as foundation and construction materials.

\section{Conflict of Interest Statement}

The authors declare that there is no conflict of interest in this manuscript.

\section{References}

[1] UNESO/AEG, Engineering Geological Maps. A Guide to their preparation. The Unesco Press, Paris, (1976) 79p

[2] J.D. Rockaway, Application of Engineering Geology to Land Use Planning in the United States. $2^{\text {nd }}$ Int. Geol. Congress IAEG 1, Sao Paulo (1974)

[3] D. Radbruch-Hall, K. Edwards, R.M. Batson, Experimental engineering geologic maps of the conterminous United States prepared using computer techniques. Bull. Int. Assoc. Engng Geol.19 (1979) 358-363

[4] M. Matula, Regional Engineering Geology of Czechslovak Carpathians Publishing House of Slovak Academy of Sciences, Bratislava. (1969) 225 pp, and Appendices I, II and III.

[5] W.R. Dearman, P.G. Fookes, Engineering Geological Mapping for Civil Engineering Practice in the U.K. Journal of Engineering Geology 7, 3, (1974) 223-256.

[6] W.R. Dearman, M.S. Money, A.D. Strachan, J.R. Coffey, Marsden, A regional engineering geological map of the Tyne and Wear County, N.E. England. Bull. Int. Assoc. Engng. Geol. 19 (1979) 5-17

[7] W.R. Dearman, An Engineering Geological Map of the soils and rocks of the United Kingdom. Bull. Int. Assoc. Engng. Geol. 25 (1982) 3-18

[8] R.W. Kahl, Role of Engineering Geology in Development of Nigeria. Geology of Nigeria. Ed. C.A. Kogbe. Elizabethan Publishing Co. Surulere (Lagos) (1976) 431-432

[9] E.G. Akpokodje, The importance of Engineering Geological Mapping in the development of the Niger Delta Basin. Bulletin of the International Association of Engineering Geology 19 (1979) 101-108

[10] S. Malomo, M.A. Oloruniwo, O. Ogunsanwo, Engineering Geological Mapping in Terrains of Tropical Weathering- An Example from Abuja, Nigeria. Journal of Engineering Geology 19 (1983) 133-148 
[11] O.A. Oyedeji et al., Systematic Engineering Geological Mapping of Benin City and Environs, Southern Nigeria. A book of proceedings of Nigeria Mining and Geosciences Society (NMGS) Ibadan (2013) 132p

[12] E.G. Gure, K. Weldearegay, G. Birhane, Engineering Geological and geotechnical appraisal of Northern Mekelle town, Tigray, Northern Ethiopia. American Scientific Research Journal for Engineering, Technology and Sciences (ASRJETS) 5(1) (2013) 23-56

[13] L. Shano, Engineering Geological Mapping of Abaya Campus Compound, Gamogofa Zone, South Ethiopia. International Journal of Scientific and Technology 6(10) (2017) 207-223

[14] O.J. Akintorinwa, F.A. Adeusi, Integration of Geophysical and Geotechnical Investigations for a proposed lecture Room complex at the Federal University of Technology, Akure, SW, Nigeria. Ozean journal of Applied Sciences 2(3) (2009) 241-254

[15] O.P. Aghamelu, B.I. Odoh, B.C.E. Egboka, A geotechnical investigation on the structural failures of building projects in parts of Awka, southeastern Nigeria. Indian Journal of Science and Technology 3(9) (2011) 1119-1124

[16] J.O. Coker, V. Makinde, J.K. Adesodun, A.O. Mustapha, Integration of Geophysical and Geotechnical Investigation for a proposed New Lecture Theatre at Federal University of Agriculture, Abeokuta, South western Nigeria. International Journal of Emerging Trends in Engineering and Development 3(5) (2013) 338-348

[17] C.N. Williams, O.J. Imarhiagbe, Geotechnical parameters of Gully erosion sites and their significance: A case study of the University of Benin Gully sites. A book of proceedings of Nigeria Mining and Geosciences Society (NMGS) Benin (2014) 121p

[18] O.O. Daodu, G.O. Adeyemi, Y.C. Ajisafe, Engineering Geophysical Investigation of a hypothetical building site in University of Ibadan, Southwestern, Nigeria A book of proceedings of Nigeria Mining and Geosciences Society (NMGS) Eko (2015) 54p

[19] S.A. Adejumo, A.O. Oyerinde, M.O. Akeem, Integrated Geophysical and Geotechnical Subsoil Evaluation for Pre-foundation study of Proposed Site of Vocational Skill and Entrepreneurship Center at The Polytechnic, Ibadan, SW, Nigeria. International Journal of Scientific \& Engineering Research, Volume 6, Issue 6, (2015) 910-917

[20] Y.A. Asiwaju-Bello et al., Unpublished Report on Geotechnical and Geophysical investigations of proposed new School of Agriculture and Agricultural Technology Building site, Federal University of Technology, Akure campus, (2015) 168p

[21] A.V. Schalkwjk, G.V. Price, Engineering Geological Mapping for urban planning in developing countries. $6^{\text {th }}$ Int. Cong. Of Int. Association of Engineering Geology, (1990) 257264

[22] D.G. Price, N. Rengers, Engineering geological mapping and photo interpretation. M. Sc. Lecture Notes, ITC, Delft, The Netherlands. Soil and Rock Characterization in the Mekele Area, Northern Ethiopia (1982)

[23] O.F. Olabode, Strength characteristics of residual soils on the Federal University of Technology, Akure (FUTA) Campus, Southwestern Nigeria. Unpublished Mtech Thesis (2015) 413p

[24] BSI 1377, Methods of testing soils for civil engineering purposes. British Standards Institution, London (1990)

[25] J.E. Bowles, Engineering Properties of soils and their measurements, $4^{\text {th }}$ International Edition. McGraw Hill Incorporated, (1984) 241p

[26] G.B. Sowers, G.F. Sowers, Introductory soil mechanics and foundations. Macmillian, NY, (1970) 556p 
[27] L.B. Underwood, Classification and identification of shales. J. soil Mech. Found. Div. ASCE, 93(11) (1967) 97-116

[28] Federal Ministry of Works and Housing (FMWH) Highway Manual Part 1 Road Design, Federal Ministry of Works and Housing, Lagos, Nigeria (1972)

[29] V.N.S. Murthy, Geotechnical Engineering: Principles and Practices of Soil Mechanics and Foundation Engineering, Marcel Dekkel Inc., 270 Madison Avenue, New York 10016, (2000) $1029 p$

[30] D.R. Snetthan, L.D. Johnson, D.M. Patrick, An evaluation of expedient methodology for identification of potentially expansive soils. Report No. FHWA-RD-77-94, United States, Army Engineers Waterways Experimental Station, Vicksburg, Mississippi (1977)

[31] C.O. Okeke, Shales: their classifications and importance to the petroleum industry. $\mathrm{PhD}$ Seminar/Special Paper in Engineering Geology and Rock Mechanics. University of Nigeria Nsukka (2005) 134p

[32] H.B. Seed, R.J. Woodward, Fundamental aspects of the Atterberg limits. J. Soil mech. Found. Div., Proceedings of ASCE, 90(SM6) (1964) 75p

[33] D.P. Coduto, Geotechnical engineering, principles and practices. Prentice-Hall, New Jersey, (1990) 759p

[34] G. Jegede, Effects of some Engineering and Geological factors on Highway failures in parts of southwestern Nigeria. Unpublished PhD thesis Federal University of Technology, Akure, (1998) 251p

[35] K.B. Woods, Compaction of Embankments. Proceedings of Highways Resources, Washington 18(2) (1937) 142-181

[36] A.B. Simon, J. Giesecke, G. Bidlo, Use of Lateritic Soils for Road Construction in North Dahomey, Engineering Geology, Amsterdam 7 (1973) 197-218

[37] M.D. Gidigasu, Laterite soil engineering. Elsevier, Amsterdam, (1980) 554p

[38] G.O. Adeyemi, Geotechnical Properties of Lateritic Soil developed over quartz schist in Ishara Area Southwestern Nigeria. Journal of Mining and Geology 38(1) (2002) 65-69

[39] F.L. Mannering, N.P. Kilareski, Principles of highway engineering and traffic analysis, $2^{\text {nd }}$ ed, Wiley, NY (1998) 340p

[40] A. Wignall, P.S. Kendrick, R. Ancil, M. Capson, Roadwork; theory and practice. $4^{\text {th }}$ ed. Butterworth-Heinemann, Oxford, (1999) 309p

[41] Federal Ministry of Works and Housing (FMWH), General Specifications for Roads and Bridge Works. Federal Government of Nigeria, Lagos 2 (1974) 305

[42] A. Hosseini, Effect of confinement pressure on bearing capacity of two samples of square and strip footing (numerical study). SpringerPlus, 3 (2014) 593-597 